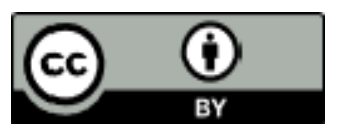

Karolien Janssens

Jan Nuyts

University of Antwerp
UDC 811.112.5'367.332.7=111

$811.112 .5^{\prime} 371=111$

Original scientific article

Accepted for publication on 20.06. 2021

https://doi.org/10.29162/jez.2021.6

\title{
On the origins of the epistemic, evidential, and subjectivity meanings in the mental state predicates: The case of Dutch
}

This paper aims to contribute to the debates about the nature of the speakerrelated meanings of the mental state predicates, on the basis of a diachronic corpus study into the semantic evolution of five such verbs in Dutch. The analyses show that each of these verbs develops its own specific profile in terms of a limited set of clearly distinguishable speaker-related meanings, viz. epistemic modality, evidentiality, and 'subjectivity'. Each of these meanings is moreover characterized by a distinctive diachronic path. The study thus also demonstrates the independent status of 'subjectivity' as a meaning category.

Key words: mental state predicates; speaker-related meanings; diachrony; epistemic modality; evidentiality; subjectivity.

\section{Introduction}

Mental state predicates (henceforth 'MSP'), such as English think, believe, or guess, count as prime examples of the diachronic process of subjectification (cf. Traugott \& Dasher 2002). Across languages, they typically develop from an 'objective' meaning, involving reference to mental states or processes, to the expression of speaker-related evaluations of states of affairs (e.g. Thompson \& Mulac 1991; Brinton 1996, 2008; Palander-Collin 1997; Diewald 2001; Nuyts 2001a, b; Apothéloz 2003; Van Bogaert 2006, 2009, 2011; Cuyckens \& Shank 2009). There is, however, no consensus on how to characterize these speaker-related meanings of the MSPs.

This paper aims to contribute to the debate, by means of a systematic corpusbased diachronic study of the semantic development of a few MSPs in Dutch. This 


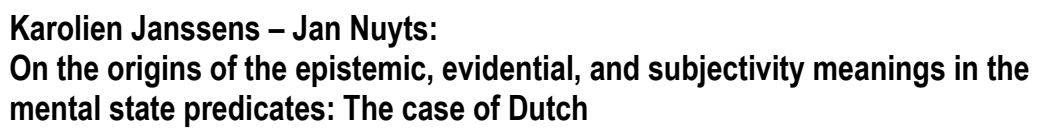

'birds' eye perspective' helps to understand both the nature of the speaker-related meanings, and the diachronic relationship between them. The analyses show that the verbs develop a few clearly distinguishable speaker-related meanings, viz. epistemic modality, evidentiality, and 'subjectivity', each of which is characterized by a distinctive diachronic path. Each verb moreover develops its own specific profile in terms of these meanings, possibly due to system-bound principles such as a tendency to avoid synonymy within the set of MSPs. In particular, the study demonstrates the independent status of 'subjectivity', the least established and most controversial among the meanings of the MSPs (cf. Nuyts 2012). ${ }^{1}$

The paper is organized as follows. In Section 2 we briefly review the literature. Section 3 defines the meaning categories figuring in the analyses, and specifies how we understand the process of subjectification. In Section 4 we sketch our corpus method, and in Section 5 we present the results. Section 6, finally, draws the implications for the notions of subjectivity and subjectification.

\section{What the literature says about the meanings of the MSPs}

In the literature there is controversy over whether the MSPs are epistemic or evidential markers. Most authors consider (1) epistemic, expressing (un)certainty about the truth of the proposition (e.g. Lyons 1977: 795; Thompson \& Mulac 1991; Givón 1993: 135; Simon-Vandenbergen 2000: 54; Nuyts 2001a). ${ }^{2}$

(1) A: Where is John?

B: I think he's in the library, but you need to check.

At least some MSPs are characterized as involving evidentiality, however, marking the nature of the speaker's information source (e.g. Van Bogaert 2006: 140 or Wierzbicka 2006: 214 on believe). Chafe (1986) even classifies all MSPs as evidential. Quite a few authors assume that some or all MSPs are both epistemic and evidential, although the share of the two meanings may vary (e.g. Wierzbicka 2006). Thus, Dendale \& Van Bogaert (2007: 74) consider French trouver 'find'

\footnotetext{
${ }^{1}$ To avoid confusion between the general notion of a 'subjective' meaning in the sense of Traugott \& Dasher (2002), and 'subjectivity' as a specific meaning category in the sense of Nuyts (2001b, 2012), we will use the term subjectivity for the latter, and speaker-related for the former.

${ }^{2}$ In examples the relevant MSP is boldfaced. The historical situation of Dutch corpus examples is indicated between square brackets after the English translation (see Section 4 for the abbreviations). We do not offer glosses for Dutch examples, only an English translation. When relevant the translation presents a literal word-for-word rendering of the original, marked with '[lit.]' if it is not felicitous in English.
} 
more evidential than croire 'believe' or penser 'think'. Nuyts (2001a: 112) assumes that verbs such as know, guess or suppose are more evidential than think or believe.

Sporadically, the speaker-related meaning of the MSPs is characterized as 'pure opinion', e.g. by Persson (1993: 7) regarding (2) (see also Simon-Vandenbergen 1998; Van Bogaert 2009). It is not always obvious what is meant by this notion, though.

(2) I think we should help him.

Our analyses will demonstrate that all these meanings are present in the Dutch MSPs. But it is important to clearly differentiate between them, since each verb has its own profile in terms of them, and since each meaning has its own diachronic path of development.

\section{Preliminary definitions}

\subsection{The meaning categories}

Before presenting our investigation of the Dutch MSPs, we should offer a definition of the meaning categories figuring in it. These are based on a careful analysis of our corpus instances, and streamlined by views on the relevant semantic domains in the literature.

In the spirit of Traugott \& Dasher's (2002) concept of subjectification, we distinguish two global categories: the objective meanings and the speaker-related meanings.

The category of objective meanings covers all uses of the MSPs involving reference to things in the 'objective world' - typically, mental states and processes, as, e.g. 'to form thoughts in the mind' in denken 'think' in (3), 'to discover' in vinden 'find' in (4), or 'to assume/expect' in vermoeden 'suppose' in (5). ${ }^{3,4}$

(3) Carolyn Coman schrijft haarfijn op wat Jimmy denkt en voelt.

'Carolyn Coman writes down minutely what Jimmy thinks and feels.' (PDD)

\footnotetext{
${ }^{3}$ For reasons of space we will not differentiate between different objective uses in the Dutch MSPs. See Janssens \& Nuyts (2014) and Janssens (2015) for a more fine-grained analysis.

${ }^{4}$ Translating the Dutch mental state verbs in the examples is not always easy, since there are often several English near equivalents, with subtly different meanings. Hence the translations do not always perfectly render the meaning of the Dutch original.
} 


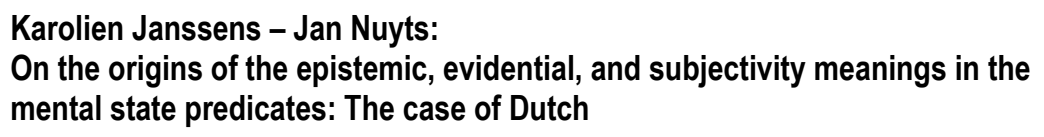

(4) Deestyt was binnen Antwerpen den roep, dat er tot Brusel in 't huys (van) den inquisituer die verloopen is na Spaengien, een briefken gevonden was.

'In those days there was rumour in Antwerp that a letter was found in Brussels, in the house of the inquisitor who fled to Spain.' (END)

(5) De naam laat het niet vermoeden maar de zaak is Engels van oorsprong.

'One would not expect it on the basis of the name, but the company is originally English' (PDD)

In the category of speaker-related meanings we distinguish a few subtypes. The first is 'epistemic modality', defined as an indication of the degree of likelihood that the state of affairs in the utterance applies in the world (Nuyts 2005). Denken in (6) expresses that the writer considers it very likely that the group size was responsible for not achieving the goals of a meeting.

(6) Ik denk dat de grootte van de groep (25 deelnemers) niet de beoogde veiligheid schiep om tot verdieping en kritisch bevragen te komen.

'I think that the group size ( 25 participants) did not create the intended feeling of safety so as to achieve deepening and critical questioning.' (PDD)

The second speaker-related category is 'inference', an evidential meaning marking that the state of affairs was inferred from other bits and pieces of observed facts or from background information (Willett 1988; de Haan 1999; Aikhenvald 2004; Nuyts 2005, 2017; Cornillie 2007). Vermoeden in (7) indicates that the police infer from the available evidence that 'the boy' was the victim of a crime.

(7) De politie vermoedt dat de jongen door een misdrijf om het leven is gekomen.

'The police suspect that the boy died due to a crime.' (PDD)

There is a clear difference with denken in (6). Even if the assessment in (6) is based on evidence, this is not at stake in the utterance. Denken exclusively marks the conclusion regarding the degree of likelihood of the state of affairs. Vermoeden in (7), however, does refer to the fact that the state of affairs is inferred from evidence, with fairly high reliability (see Nuyts 2017 on the difference).

The third speaker-related meaning is what we will call 'memory'. This involves the marking that the state of affairs has been retrieved from memory, but the recall is considered not entirely reliable $-(8)$ is an example. 
(8) Laat ik met [een jeugdherinnering] eindigen. In een jeugdkamp waar ik aan meedeed toen ik een jaar of veertien, vijftien was, werd zo nu en dan het lied aangeheven: [...] Ik geloof niet dat er die tijd over enige andere Nederlandse politicus zulke liedjes bestonden.

'Let me conclude with a memory from my youth. In a youth camp in which I participated when I was around fourteen, fifteen, we occasionally sang a song: [...] As far as I can remember [lit.: I believe], in those days no such songs existed about any other Dutch politician.' (PDD)

This meaning is only sporadically mentioned in the literature, and it is at least sometimes considered a type of evidentiality (e.g. Jakobson 1957/1971: 135; Ifantidou 2001: 6-7; Schneider 2007: 126-127). We will handle it as a separate meaning in our analyses, but when relevant we will consider it part of evidentiality, assuming that its categorization as such is plausible.

The last speaker-related meaning is 'subjectivity', as one of the poles in the subjectivity vs intersubjectivity distinction defined in Nuyts (1992, 2001b, 2012). This dimension involves the marking of whether what the speaker is saying is his/her own strictly personal opinion (subjectivity), vs renders a view s/he shares with a wider group of people, possibly including the hearer (intersubjectivity). Denken in (9) is used as a subjectivity marker.

(9) Ik denk niet dat we dierenwelzijn in evenwicht moeten brengen met onze economische belangen, maar in evenwicht moeten brengen met onze ware behoeften.

'I don't think we have to bring animal welfare into balance with our economic interests, but bring it in balance with our true needs.' (PDD)

Contrary to the epistemic use of denken in (6), the writer is not estimating the chances that it is morally necessary to bring animal welfare into balance with our needs rather than with economy (this meaning construal does not even make sense). $\mathrm{S} /$ he is indicating that it is his/her personal opinion that we should do so.

Since this is the least established among the meanings of the MSPs, let us elaborate a bit on its background. Subjectivity differs from epistemic modality or types of evidentiality in terms of its semantic status (cf. Nuyts 2017). While the latter qualify states of affairs, and do not normally co-occur in a clause (see Nuyts 2009), subjectivity co-occurs with and qualifies other speaker-related meanings such as epistemic or evidential ones, or deontic ones, as in (9) (the subjectivity concerns the writer's assessment of what is morally good or bad in terms of animal welfare). 


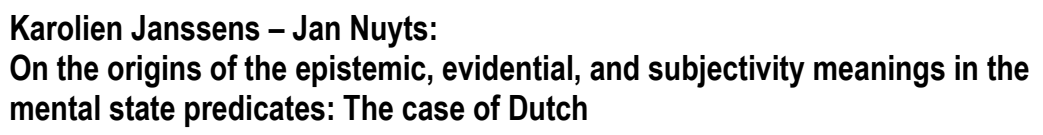

The dimension was originally postulated to account for the difference between epistemic expressions such as I think John is ill vs It is probable that John is ill (Nuyts 1992, 2001b). In the modality literature this difference is traditionally explained in terms of two different types of epistemic modality, viz. (respectively) subjective epistemic vs objective epistemic (cf. e.g. Lyons 1977). In the alternative analysis the two expressions are considered to express the same category of epistemic modality, but to differ in terms of the separate semantic dimension of subjectivity vs intersubjectivity. This dimension is coded by the syntactic pattern of the epistemic expression: it emerges through the choice of subject in predicative modal forms. A first person subject (as in I think, but also e.g. I am sure) triggers a subjectivity reading, an impersonal subject (as in It is probable/certain) triggers an intersubjectivity reading. Non-predicative expressions such as adverbs or auxiliaries are neutral in these terms. But the dimension is also coded by independent markers (cf. Nuyts 2012, 2014), including Dutch denken as in (9) (or English think in equivalent uses). ${ }^{5}$

So, in order to avoid confusion, note that an epistemic use of denken of the kind in (6) is also subjective in this analysis. But the difference with pure subjectivity uses of the kind in (9) is that denken in (6) is centrally epistemic, and receives a subjective flavor due to its grammatical context (its subject; i.e. the subjectivity is not inherent in the meaning of the MSP). In (9), however, there is no epistemic meaning involved, and the MSP as such marks subjectivity, as its central meaning (hence in the analyses below we do not code epistemic uses of denken of the kind in (6) as marking subjectivity).

It is tempting to assume that this pure subjectivity use historically emerged out of the epistemic use, through loss of the epistemic meaning and transfer of the subjectivity meaning originally coded in the grammatical pattern to the MSP itself. Let's see whether this is confirmed by our analyses.

\subsection{Subjectification}

We should also briefly explain how we interpret the process of subjectification. The traditional definition, in Traugott \& Dasher's (2002) terms, was offered in the introduction. As argued in Nuyts (2012; see also Byloo \& Nuyts 2014; Nuyts \& Byloo 2015), the concept can be operationalized in terms of the concept of the hierarchy of 'qualificational categories'. Example (10) offers a simple and theory-

\footnotetext{
${ }^{5}$ Nuyts (2001b) considered this dimension a subtype of evidentiality, but there are strong arguments against this analysis (see Nuyts 2012, 2014, 2017).
} 
neutral version of this hierarchy (see Nuyts 2001a for discussion of more sophisticated versions proposed in the literature). ${ }^{6}$

(10) $>$ inferential evidentiality

$>$ epistemic modality

$>$ deontic modality

$>$ time

$>$ quantitative aspect / dynamic modality

$>$ phasal aspect

$>$ state of affairs

This hierarchy was originally developed to account for the relative extension of semantic scope of the qualificational categories. The higher in the hierarchy, the wider the scope: categories have scope over those below them, but not over those above them. However, the hierarchy also correlates with degrees of speaker involvement (see Nuyts 2009, 2021). The higher in the hierarchy, the more a speakers needs to do in terms of drawing in and interpreting external information in order to qualify the state of affairs, hence the more room for subjectivity (in Traugott's sense) in the qualification. In that perspective subjectification can be defined as the process by which the meaning of an element gradually climbs up the hierarchy in (10).

The category of subjectivity, as one of the meanings of the MSPs (cf. Section 3.1 ), is absent in the hierarchy in (10). This is no accidental omission. We return to this issue in Section 6.

\section{Method}

The corpus study covers the Dutch MSPs denken 'think', dunken 'methinks', geloven 'believe', vinden 'find', and vermoeden 'suppose'. This selection is motivated by the frequency of the verbs in present day Dutch, and by the goal to obtain interesting semantic oppositions within the set in the range of the speaker-related

\footnotetext{
${ }^{6}$ The category 'memory' is not mentioned in the hierarchy, but we assume that it aligns with inferential evidentiality (see Nuyts 2017 on the status of the other evidential categories, experienced and hearsay). The other categories in the hierarchy, to the extent that they have not been defined above, will hopefully be sufficiently familiar to the reader so as not to require a formal definition here. See Nuyts (2021) for definitions and more information.
} 


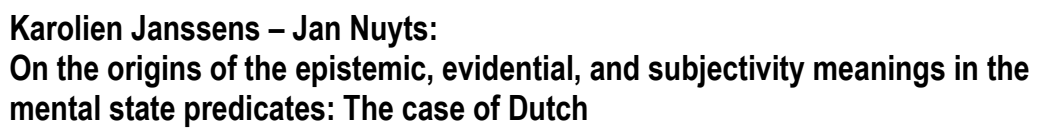

meanings (this was estimated on the basis of pilot queries regarding the situation in current Dutch). Dunken is highly infrequent in current Dutch but is included because of its historical tie with denken (both verbs have the same ancestor).

We use samples of these verbs from four stages of the language: Old Dutch (OD, before 1150), Early Middle Dutch (EMD, 1200-1360), Early New Dutch (END, 1550-1650), and Present Day Dutch (PDD, after 1950). ${ }^{7}$ Samples include 200 instances per verb per period (or, in case the materials did not contain 200, as many as available) ${ }^{8}$ They were compiled from different electronically available sources, including the CD-ROM Middelnederlands (1998), the Digitale Bibliotheek voor de Nederlandse Letteren (www.dbnl.org, which covers a wide range of texts from different genres, pace its name), the ConDiv-corpus (Grondelaers et al. 2000), and trustworthy websites of journals, newspapers, official organizations, etc. The selection of instances was random, yet delimited by criteria such as representativity and comparability across periods (geographically and in terms of genres).

In the semantic analyses we have always considered the wider context of instances. A significant part of the samples, including all difficult instances, was/were analyzed independently by the two authors. Cases of disagreement were resolved through discussion. Since ambiguity is an important signal for diachronic links between meanings, ambiguous instances were not forced into one category but were labeled for all possible readings. Marking an instance as ambiguous was never the result of disagreement between the assessors: in all cases they agreed on the existence of ambiguity, and on the alternative readings.

Statistical significance is checked by means of Fisher's exact test.

\section{Results}

\subsection{Overview}

Tables 1 to 5 present the results for the different MSPs. They show the absolute frequencies of the meanings (' $n$ '), as well as their relative share ('\%') in the total number of instances per time slot as indicated between brackets in the top row. Ambiguous instances are listed separately.

\footnotetext{
${ }^{7}$ In this paper we only offer data for written PDD. Janssens \& Nuyts (2014) and Janssens (2015) also analyze spoken PDD data, but for the present purpose these do not bring significant new insights, hence they are omitted for reasons of space.

${ }^{8}$ The problem of sample size applies especially for OD, due to the fact that there are very few texts remaining from this period.
} 
Table 1. Meaning evolution denken

\begin{tabular}{|c|c|c|c|c|c|c|c|c|}
\hline & \multicolumn{2}{|c|}{$\begin{array}{l}\text { OD } \\
(n=14)\end{array}$} & \multicolumn{2}{|c|}{$\begin{array}{l}\text { EMD } \\
(n=188)\end{array}$} & \multicolumn{2}{|c|}{$\begin{array}{l}\text { END } \\
(n=200)\end{array}$} & \multicolumn{2}{|c|}{$\begin{array}{l}\text { PDD } \\
(n=200)\end{array}$} \\
\hline & $\mathrm{n}$ & $\%$ & $\mathrm{n}$ & $\%$ & $\mathrm{n}$ & $\%$ & $\mathrm{n}$ & $\%$ \\
\hline Objective & 13 & 92.9 & 147 & 78.2 & 163 & 81.5 & 113 & 56.5 \\
\hline Epistemic & 1 & 7.1 & 15 & 8 & 29 & 14.5 & 72 & 36 \\
\hline Subjectivity & & & & & & & 10 & 5 \\
\hline Obj/Epi & & & 26 & 13.8 & 7 & 3.5 & 3 & 1.5 \\
\hline Epi/Subj & & & & & 1 & 0.5 & 2 & 1 \\
\hline
\end{tabular}

Table 2. Meaning evolution dunken

\begin{tabular}{l|llllll|ll} 
& $\begin{array}{l}\text { OD } \\
\text { (n=4) }\end{array}$ & & \multicolumn{2}{l}{$\begin{array}{l}\text { EMD } \\
(\mathrm{n}=200)\end{array}$} & \multicolumn{2}{c}{$\begin{array}{l}\text { END } \\
(\mathrm{n}=200)\end{array}$} & \multicolumn{3}{c}{$\begin{array}{l}\text { PDD } \\
(\mathrm{n}=26)\end{array}$} \\
& $\mathrm{n}$ & $\%$ & $\mathrm{n}$ & $\%$ & $\mathrm{n}$ & $\%$ & $\mathrm{n}$ & $\%$ \\
\hline Objective & 1 & 25 & 42 & 21 & 29 & 14.5 & & \\
Epistemic & & & 19 & 9.5 & 22 & 11 & 4 & 15.4 \\
Subjectivity & & & 79 & 39.5 & 94 & 47 & 15 & 57.7 \\
Obj/Epi & & & 10 & 5 & 19 & 9.5 & & \\
Obj/Subj & 3 & 75 & 36 & 18 & 26 & 13 & 2 & 7.7 \\
Epi/Subj & & & 8 & 4 & 8 & 4 & 5 & 19.2 \\
Obj/Epi/Subj & & & 6 & 3 & 2 & 1 & & \\
\hline
\end{tabular}

Table 3. Meaning evolution geloven

\begin{tabular}{|c|c|c|c|c|c|c|c|c|}
\hline & \multicolumn{2}{|c|}{$\begin{array}{l}\text { OD } \\
(n=7)\end{array}$} & \multicolumn{2}{|c|}{$\begin{array}{l}\text { EMD } \\
(n=200)\end{array}$} & \multicolumn{2}{|c|}{$\begin{array}{l}\text { END } \\
(n=200)\end{array}$} & \multicolumn{2}{|c|}{$\begin{array}{l}\text { PDD } \\
(n=200)\end{array}$} \\
\hline & $\mathrm{n}$ & $\%$ & $\mathrm{n}$ & $\%$ & $\mathrm{n}$ & $\%$ & $\mathrm{n}$ & $\%$ \\
\hline Objective & 7 & 100 & 199 & 99.5 & 155 & 77.5 & 176 & 88 \\
\hline Epistemic & & & & & 14 & 7 & 6 & 3 \\
\hline Memory & & & & & & & 3 & 1.5 \\
\hline Subjectivity & & & & & & & 1 & 0.5 \\
\hline Obj/Epi & & & 1 & 0.5 & 26 & 13 & 5 & 2.5 \\
\hline $\mathrm{Obj} / \mathrm{Subj}$ & & & & & 1 & 0.5 & 5 & 2.5 \\
\hline Epi/Subj & & & & & 1 & 0.5 & 3 & 1.5 \\
\hline Epi/Mem & & & & & 3 & 1.5 & & \\
\hline Obj/Epi/Subj & & & & & & & 1 & 0.5 \\
\hline
\end{tabular}


Karolien Janssens - Jan Nuyts:

On the origins of the epistemic, evidential, and subjectivity meanings in the mental state predicates: The case of Dutch

Table 4. Meaning evolution vinden

\begin{tabular}{|c|c|c|c|c|c|c|c|c|}
\hline & \multicolumn{2}{|c|}{$\begin{array}{l}\text { OD } \\
(n=29)\end{array}$} & \multicolumn{2}{|c|}{$\begin{array}{l}\text { EMD } \\
(n=200)\end{array}$} & \multicolumn{2}{|c|}{$\begin{array}{l}\text { END } \\
(n=200)\end{array}$} & \multicolumn{2}{|c|}{$\begin{array}{l}\text { PDD } \\
(n=200)\end{array}$} \\
\hline & $\mathrm{n}$ & $\%$ & $\mathrm{n}$ & $\%$ & $\mathrm{n}$ & $\%$ & $\mathrm{~N}$ & $\%$ \\
\hline Objective & 27 & 93.1 & 189 & 94.5 & 174 & 87 & 109 & 54.5 \\
\hline Subjectivity & & & 3 & 1.5 & 14 & 7 & 86 & 43 \\
\hline Obj/Subj & 2 & 6.9 & 8 & 4 & 12 & 6 & 5 & 2.5 \\
\hline
\end{tabular}

Table 5. Meaning evolution vermoeden

\begin{tabular}{l|lllllllll} 
& $\begin{array}{l}\text { OD } \\
(\mathrm{n}=0)\end{array}$ & & \multicolumn{2}{l}{$\begin{array}{l}\text { EMD } \\
(\mathrm{n}=28)\end{array}$} & \multicolumn{3}{c}{$\begin{array}{l}\text { END } \\
(\mathrm{n}=200)\end{array}$} & \multicolumn{2}{c}{$\begin{array}{l}\text { PDD } \\
(\mathrm{n}=200)\end{array}$} \\
& $\mathrm{n}$ & $\%$ & $\mathrm{n}$ & $\%$ & $\mathrm{n}$ & $\%$ & $\mathrm{n}$ & $\%$ \\
\hline $\begin{array}{l}\text { Objective } \\
\text { Inferential }\end{array}$ & & & 27 & 96.4 & 193 & 96.5 & 139 & 69.5 \\
Obj/Inf & & & & & & & 33 & 16.5 \\
\hline
\end{tabular}

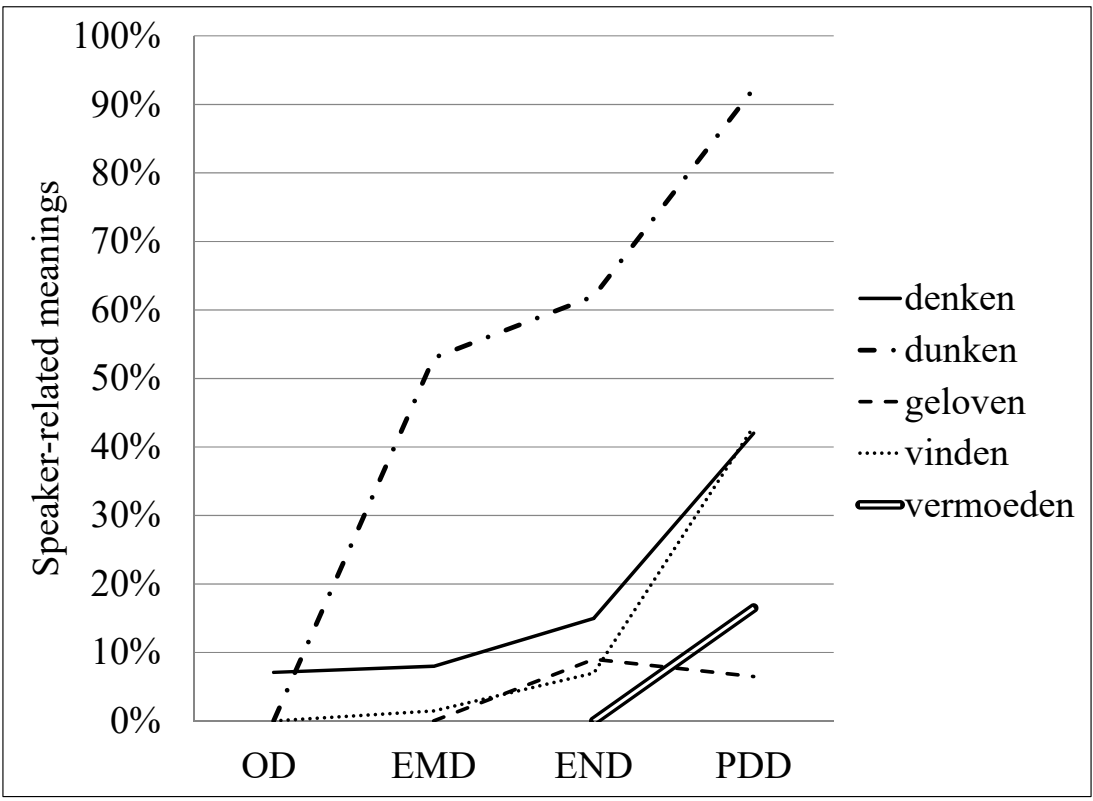

Figure 1. Evolution of speaker-related meanings 
Figure 1 visualizes the evolution of the share of instances with a speaker-related meaning of any type in the different MSPs (excluding instances ambiguous between a speaker-related and an objective meaning). These global evolutions are highly significant (.000) in all MSPs.

The tables and figure show that, in line with expectation, all verbs undergo a process of subjectification. There are considerable differences between the individual verbs, however. Denken and vinden show a similar timing and intensity in their evolution (though they differ considerably in what speaker-related meanings they develop, see below). Dunken subjectifies much more intensively. Vermoeden starts to subjectivize much later (in PDD; instances with objective/speaker-related ambiguity already occur in EMD, though). Geloven, finally, is hesitant in its subjectification process (but the slight decrease in its speaker-related meanings between END and PDD is statistically not significant).

\subsection{The origins of the speaker-related meanings}

Let us take a closer look at the diachronic origins of each of the speaker-related categories.

\subsubsection{Epistemic modality}

This meaning occurs in denken, dunken, and geloven .

The tables for denken and geloven leave little doubt that the epistemic use emerged out of the objective meanings in these verbs. ${ }^{9}$ In denken the birth of the epistemic meaning may precede our data, but it increases continuously from EMD to PDD. In geloven it emerges in EMD and breaks through in END, but loses some ground again in PDD. (In denken the global increase in the epistemic meaning is highly significant [.000], both in the unambiguous instances separately, and in the unambiguous and ambiguous ones together. In geloven the increase from EMD to END is only significant [.000] if the ambiguous instances are included. The drop from END to PDD is also significant [.000] if the ambiguous instances are included.) Both verbs show frequent ambiguity between the objective and epistemic

\footnotetext{
${ }^{9}$ This shows that the traditional concept of the typical diachronic pathway of the modal meanings, as found in the modal auxiliaries in many languages, viz. 'objective $>$ dynamic $>$ deontic $>$ epistemic', cannot be generalized (even for the modals it is not entirely unproblematic, though; see Byloo \& Nuyts 2014). The epistemic meaning may have entirely different origins, not involving any other modal meanings.
} 


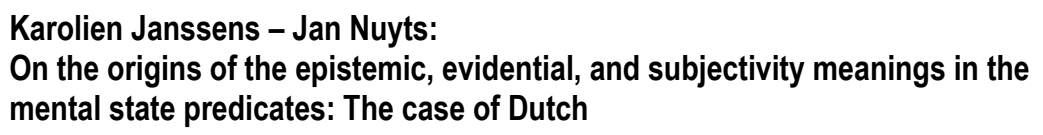

meanings in the early stages of the breakthrough of their epistemic meaning. This ambiguity occurs in $63.4 \%$ of the instances with an epistemic meaning in denken in EMD, in $59.1 \%$ of them in geloven in END. In denken this type of ambiguity decreases drastically in END and PDD. In geloven it also decreases but remains relatively high even in PDD, at $40.0 \%$. This suggests that the epistemic meaning was still unstable in these verbs in EMD and END, respectively, it still depending to a considerable extent on conversational implicatures raised in objective uses. It gradually stabilizes as an independent meaning in later periods, though this process happens more slowly in geloven. The ambiguous instances also show how the logical step from the objective to the epistemic meaning may have happened in both verbs. Many of them feature typical bridging contexts. Geloven in (11), e.g., can either mean that the writer cannot accept the idea that Aurelia is the cause of the fight (the most common objective meaning in this verb), or that $\mathrm{s} /$ he doubts that this is the case (i.e. epistemic). The difference between the two readings is small.

(11) ' $k$ Geloof heer, immer niet Aurelia d' oorsprong van het gevecht zoud wesen.

'I still do not believe, Lord, that Aurelia would be the cause of the fight.' (END)

In dunken the epistemic meaning is already fairly prominent in EMD (its absence in OD is most likely an accidental gap due to the small sample), and its share remains stable in END and PDD (the evolution is statistically not significant). This suggests that this meaning is well established in these periods. The number of ambiguous instances featuring it is quite high in EMD and END, but in this case this is probably not a symptom of an emergent meaning, but of the decay of the verb: dunken is nearly obsolete in PDD, and this process no doubt started at least in EMD, along with the decline of other impersonal verbs in Dutch (see Van der Horst 2008). Epistemic modality is frequently ambiguous with both the objective meaning and subjectivity in this verb (though more with the former than with the latter), but it is hard to draw conclusions from this in terms of meaning developments. At least, there is no reason to doubt the plausibility of a scenario comparable to that in denken and geloven (even if situated much earlier in time).

\subsubsection{Evidentiality}

The memory meaning only occurs in geloven. It is very recent: it appears in ambiguous instances in END, and unambiguously in PDD. But it remains marginal. It is only ambiguous with epistemic modality, as in the example in (12). Even in the 
wider context it remains unclear whether the author considers it likely that the order was given by the mayors, or whether he seems to remember this.

(12) In aller haest hadden die van de Oude Kamer, door last geloof ik van de Heeren Burgemeesteren, een Toneel voor de Waegh opgesmeten.

'In a hurry the members of the Old Chamber, by order, I believe/if I remember well, of the mayors, had erected a theater in front of the weighing house.' (END)

The number of instances is too small to draw conclusions from this ambiguity pattern, however.

The inferential meaning is confined to vermoeden. It occurs sporadically in ambiguous instances in EMD and END, but acquires a substantial share in PDD, also in unambiguous instances (the global evolution is highly significant [.000], both with and without the ambiguous instances). The high number of ambiguous instances (45.9\% of all instances with an inferential meaning) suggests that it is not really stable yet, though. It undoubtedly originates in the objective meaning, as the only other meaning type occurring in this verb, hence as the only alternative in ambiguous instances. This stands to reason: it is a small step from 'to hypothesize' (objective) to 'to infer' (speaker-related).

In sum, against expectation, the evidential meanings turn out to play a minor role in the diachrony of our set of verbs. Follow-up research will have to show whether the situation is different in other Dutch MSPs (most of which are far less frequent and/or show far less speaker-related uses in PDD, though).

\subsubsection{Subjectivity}

The subjectivity meaning occurs in all verbs except vermoeden.

It is very recent in denken and geloven: it first emerges in ambiguous instances in END and in unambiguous instances in PDD in both verbs. It remains a minor meaning until today in both (the evolution is statistically significant [.000] for both, however, even though for geloven only when the ambiguous instances are included).

In denken it is not implausible to assume that it emerged out of the epistemic meaning, since it appears much later in time than the latter, and since the, admittedly very few, ambiguous instances exclusively feature epistemic modality as the alternative reading. Example (13), e.g., seems to involve a typical bridging context. 


\section{Karolien Janssens - Jan Nuyts: \\ On the origins of the epistemic, evidential, and subjectivity meanings in the mental state predicates: The case of Dutch}

(13) Ik denk dat dat maar een klein deel van het probleem is.

'I think that is only a small part of the problem.' (PDD)

It is a small logical step from the reading that the writer considers it likely that 'that' is only a small part of the problem (epistemic), to the reading in which $\mathrm{s} / \mathrm{he}$ expresses his/her personal opinion that this is the case (subjectivity). The situation in this MSP thus appears in line with our speculations about the origins of the subjectivity meaning in Section 3.1.

The other MSPs show that there may be other scenarios as well, though. Thus, also in geloven the subjectivity meaning emerges later than the epistemic meaning, but in the few ambiguous instances both the objective meaning and epistemic modality occur as alternatives, hence both could be the source.

Dunken suggests even more strongly that the situation is more complex. Subjectivity is the absolutely dominant meaning in this (now archaic) verb all through its history (the increase from EMD till PDD is statistically not significant; that it only occurs ambiguously in OD may be due to the small sample). It is far more important than the epistemic use. This does not necessarily mean that the subjectivity meaning cannot have emerged out of the epistemic use. Timing offers no evidence, since the emergence of both meanings precedes our data. Even if the massive occurrence of ambiguity may be due to the decay of the verb (cf. Section 5.2.1), the ambiguity patterns cast some doubt, though. The subjectivity meaning is far more often ambiguous with the objective than with the epistemic meaning, and many of the instances suggest that a development from the objective to the subjectivity meaning is not unthinkable, including (14). ${ }^{10}$

(14) Als ene manne dunket, dat [die] arsedie lelik is. sone ge[raak]t oeme nit te genese.

'If someone experiences/thinks this medicine as/is disgusting, it will not heal him.' (EMD)

This may either mean that someone's physical experience (the objective meaning) of a bad taste will prevent him/her from taking the medicine, hence from healing, or that if someone is personally convinced that it has a bad taste, s/he will not take it and will not heal (subjectivity). It is only a small step from one to the other.

Vinden does not even have an epistemic meaning, hence its subjectivity use cannot have emerged from it. The only other, no doubt older, meaning in this verb is the objective one. Subjectivity is present from OD/EMD onwards and grows

${ }^{10}$ The square brackets mark reconstructed parts. 
steadily towards PDD (the evolution is statistically significant [.000] both for the unambiguous instances separately and for the unambiguous and ambiguous instances together). The evolution in the ambiguous instances conforms to the picture of a gradually stabilizing meaning: their share in the subjectivity instances decreases from $100 \%$ in OD (but mind the small sample) to $72.7 \%$ in EMD, $19.4 \%$ in END, and 5.5\% in PDD. The link between the objective and subjectivity meanings is obvious in many of them, including (15).

(15) $N u$ is voorder mijn meyninge, te beschrijven van de eerste Vinders aen het Leven der oude Schilders, vermijdende (so veel ick magh) alle confusie, om (so veel doenlijck is) yeghelijck Constenaer t'onderscheyden, en zijn wercken by malcander te versamelen, dewijle ickse seer vermengt, en onder een vergoten vinde.

'I now furthermore mean to write about the first discoverers of the life of the old painters, trying to avoid (as much as I can) all confusion, so as to distinguish (as much as possible) every artist, and sort out his work, [lit.:] while I find them very mixed up and disordered.' (END)

This may mean either, literally, that the writer encounters the works of the artists in a mixed up state in earlier descriptions (the objective meaning), or that $\mathrm{s} / \mathrm{he}$ is of the opinion that the works are mixed up by the earlier writers (subjectivity). This is a clear bridging context.

In sum, the subjectivity meaning is the most common speaker-related meaning in our set of Dutch MSPs. Apparently, the semantic nature of these verbs is good soil for it. But it is far less strongly intertwined with the epistemic meaning than one might expect.

\subsection{Semantic interactions between the MSPS}

A closer look at the correlation between the developments in the five MSPs suggests that they may have influenced each other to some extent. To see this, Figures 2-4 show the share per time slot of the different meanings in each of the verbs (cf. Tables 1-5). We omit OD because of the limited data. In order not to complicate matters, the charts only cover the unambiguous instances. 
Karolien Janssens - Jan Nuyts:

On the origins of the epistemic, evidential, and subjectivity meanings in the mental state predicates: The case of Dutch

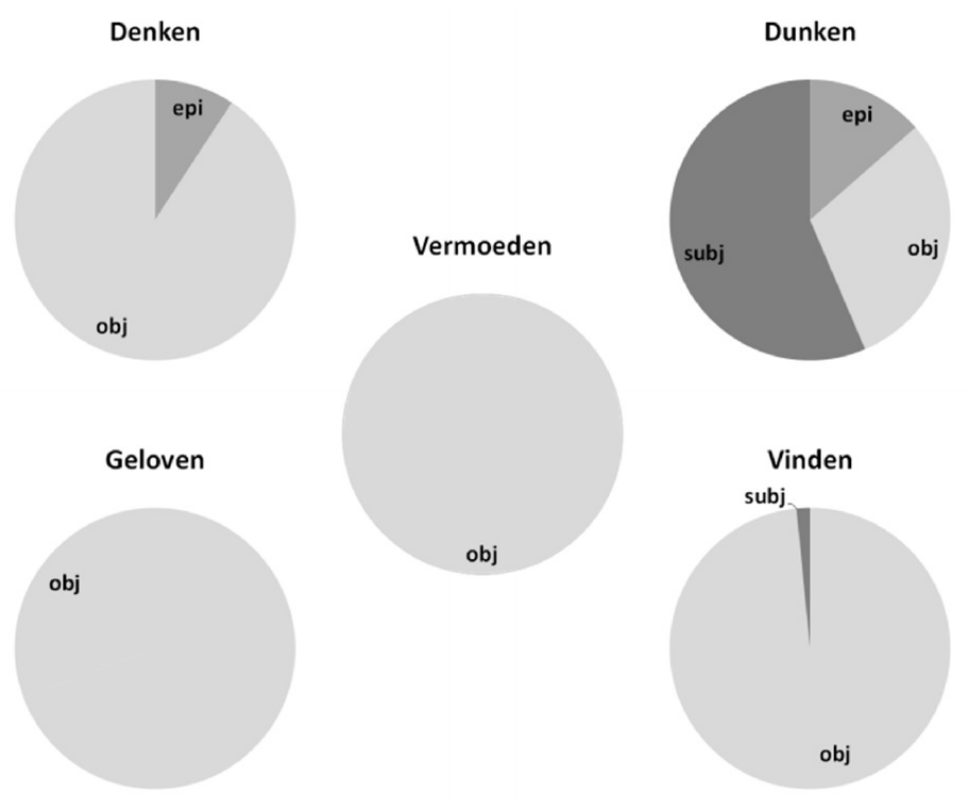

Figure 2. Share of the meanings in the MSPs in EMD
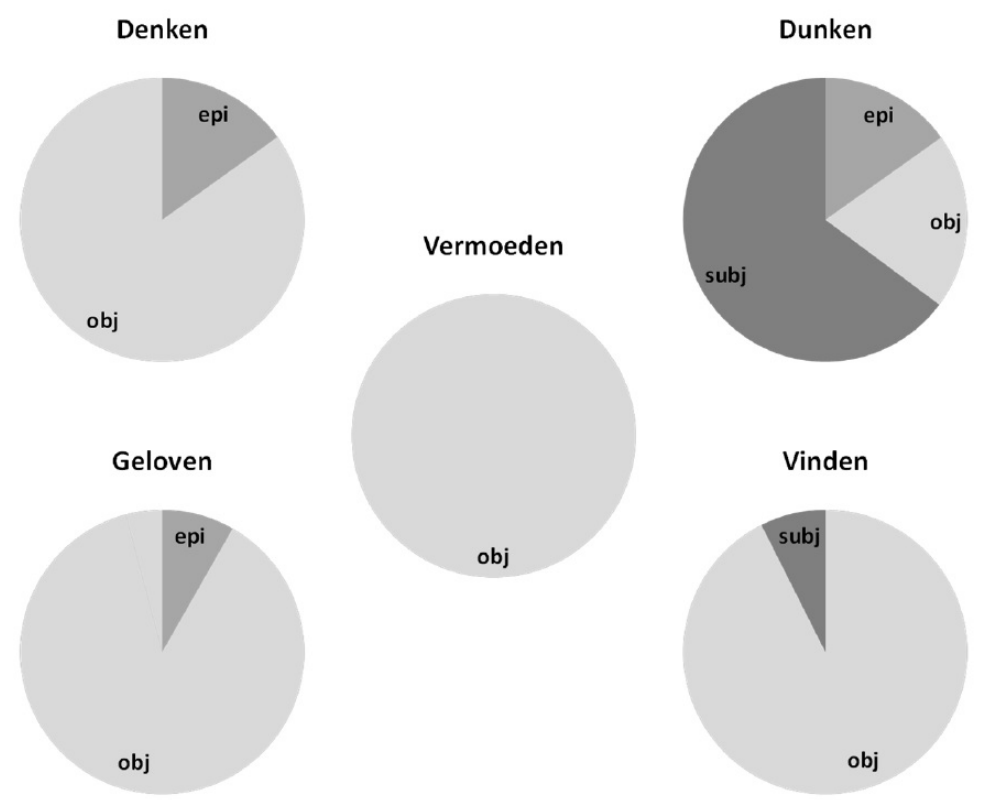

Figure 3. Share of the meanings in the MSPs in END 


\section{EZIKOSLOVLJE}

22.2 (2021): $227-250$
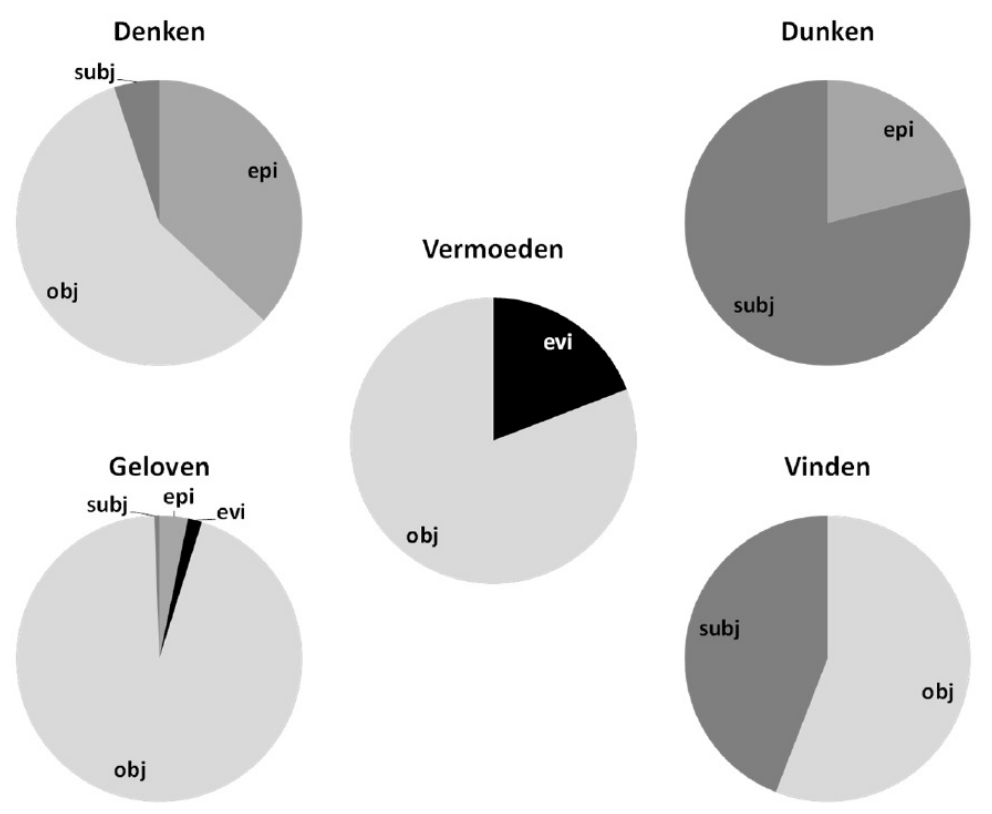

Figure 4. Share of the meanings in the MSPs in PDD

In EMD (Figure 2) epistemic modality is most prominent in dunken, but its incidence in denken is only slightly lower. The subjectivity use is very strong in dunken, and is a minor category in vinden. Vermoeden and geloven do not show unambiguous instances with a speaker-related meaning yet. In the evolution towards END (Figure 3), epistemic modality increases in denken and dunken and emerges in geloven. The subjectivity meaning of dunken and vinden increases as well. Vermoeden remains exclusively objective in its unambiguous instances. In PDD (Figure 4) the epistemic meaning increases further in denken and in (nearly obsolete) dunken, but decreases in geloven. The subjectivity use increases further in dunken and even more so in vinden, and it emerges in denken and geloven. So denken and geloven now feature the same speaker-related meanings as dunken, even if in different proportions. The evidential meaning emerges, minimally in geloven, but strongly in vermoeden.

These observations suggest interactions between the verbs in two ways. Firstly, the evolution in denken and possibly also in geloven and vinden may be influenced by the decline of the most subjectified verb in the set, dunken. These verbs develop speaker-related meanings that are strongly present in dunken: epistemic modality, and especially subjectivity. They seem to gradually fill in the semantic gap left by dunken. Possibly, this set of verbs is so important for expressing these kinds of 


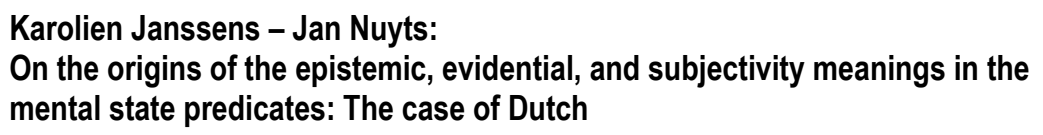

meanings, and especially subjectivity, that the language does not want to lose this function.

Secondly, in the process of filling the gap left by dunken the principle of 'no synonymy' may have been at work (cf. e.g. Bolinger 1968; Croft 2000), resulting in a tendency for the replacing verbs to diverge. One may expect such a replacement process to happen in a quite disorderly way. Any sufficiently related verb is a candidate to take over some of the meanings. This may explain why three verbs develop the subjectivity meaning, the dominant use in dunken and the most prominent one in the entire set. It may also explain why two verbs, denken and geloven, develop an epistemic meaning. However, the fact that in PDD this epistemic meaning increases further in denken but decreases in geloven, and that geloven also develops an evidential meaning while denken does not, might signal a tendency for these verbs to diverge. Denken appears to be profiling itself as the prime MSP for expressing epistemic modality, and geloven is gradually exploring other territory. The fact that vinden and vermoeden never developed an epistemic meaning but have gone in other directions in their subjectification process might have the same cause. Both geloven and vermoeden develop an evidential meaning, but a different one in each ('memory' vs 'inference'), so there is again no synonymy.

This demonstrates again that the process of subjectification may be less independent than is sometimes assumed in the literature. It may be sensitive to other factors of language change, notably to 'system-bound' factors such as the 'no synonymy' principle. This principle was also found at work, even in a much more stringent way, in the subjectification process in the Dutch modals (see Nuyts \& Byloo 2015). That its effect is less stringent in the MSPs than in the modals should not come as a surprise, since the grammatical system of the modals is more rigid than the lexical system of the MSPs.

At the same time, these observations underscore that the different speakerrelated meanings at stake in the MSPs are clearly distinct categories, which show mutual 'sensitivity'.

\section{Subjectivity and subjectification}

In the analysis in Section 5 subjectivity stands out as an important and distinctive meaning in the MSPs. It is far less correlated with the epistemic meaning than one might assume, or than is sometimes suggested in the literature. It may develop out of the epistemic meaning (as in denken and possibly in part in geloven), but it can also have other sources (as in vinden, and possibly in dunken). There is a special tie 


\section{EZIKOSLOVLJE \\ 22.2 (2021): 227-250}

between subjectivity and epistemic modality in the sense that the epistemic use of the MSPs may also be called subjective (cf. Section 3.1). Nevertheless, the pure subjectivity use of the MSPs is only partly related to the (subjective) epistemic use.

What do our analyses tell us about the status of subjectivity in relation to the qualificational hierarchy in (10) (see Section 3.2), and to the inferential evidential and epistemic meanings in particular? Nuyts $(2012,2017)$ offers a number of arguments against including subjectivity in the hierarchy. The different behavior of this category as compared to epistemic modality and inferentiality, as discussed in Section 3.1, is a symptom of a more profound difference. Subjectivity does not accord with the rationale behind the qualificational hierarchy as sketched in Section 3.2. It is by definition strongly speaker-related, which might suggest it is very high in the hierarchy. But unlike the categories high in the hierarchy (such as inferential evidentiality and epistemic modality) it would not seem to require much 'mental work' in terms of assessing and interpreting a state of affairs against the background of other information - it only requires knowing the ideas of others and registering (dis)agreement with them. Unlike the categories in the hierarchy, it does not even seem to involve a qualification of the state of affairs (the state of affairs remains 'untouched'). It rather concerns the position of the speaker relative to others, even if with relevance to the state of affairs. For these reasons subjectivity must be assumed to be beyond the qualificational hierarchy in (10), even if intimately related to it.

Our present investigation does not add anything to this analysis, but it does offer reason for reflection on the relations between the qualificational hierarchy and the concept of subjectification (in the sense of Traugott \& Dasher 2002; cf. Section 3.2). If subjectivity is beyond the qualificational hierarchy, is the emergence of this meaning (be it out of an objective meaning, or out of epistemic modality) a case of subjectification? What does the answer mean for the definition of subjectification in terms of the qualificational hierarchy (cf. Section 3.2)?

If the definition of subjectification as climbing up the hierarchy in (10) is correct, the emergence of the subjectivity meaning is not subjectification anymore, but something else. Might it be intersubjectification, as the follow-up process in Traugott \& Dasher's (2002) complex concept of (inter)subjectification? In the analysis in Nuyts (2012; cf. also Byloo \& Nuyts 2014; Nuyts \& Byloo 2015), in intersubjectification a linguistic element semantically leaves the qualificational hierarchy (which is essentially conceptual, i.e. concerning the way we conceive of the world) to assume a function in the realm of communication and interaction management, e.g. as a hedging device, or an illocutionary marker, or a text or discourse 


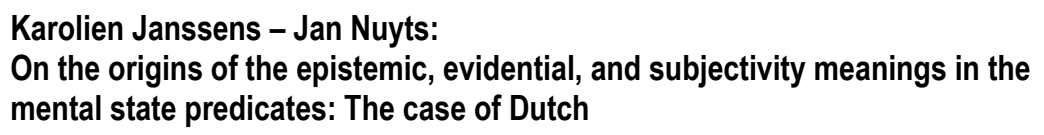

marker (e.g. a sentence connector). The subjectivity use of, e.g., an MSP does have an important discursive function, to regulate the mutual positions of the interlocutors in argumentative situations (cf. Nuyts 2015). Nevertheless, the category remains a matter of the way the speaker conceives of the world (specifically: of how $\mathrm{s} / \mathrm{he}$ conceives of his/her own position in the world, in connection with some state of affairs). Hence the development of the subjectivity meaning can hardly be considered an instance of intersubjectification.

If so, unless we assume there is a third type of evolution next to subjectification and intersubjectification, the emergence of subjectivity is subjectification. But then the definition of this process exclusively in terms of the hierarchy in (10) needs to be modified. We have to assume that the process extends beyond the hierarchy to cover speaker-centered meanings. As argued in Nuyts $(2012,2017)$, subjectivity is not the only category of this kind: 'mirativity', as the marking that information provided in an utterance is surprising and new to the speaker (cf. DeLancey 1997, 2001 ), is another one. We are not aware of research on the diachronic origins of mirativity, but it would be helpful to further our understanding of the issues at stake.

\section{Conclusion}

In sum, we hope to have shown that, in spite of some overlap, the different Dutch MSPs have a clearly identifiable meaning profile in terms of their speaker-related meanings. They are not vague in terms of these meanings. Even when there is ambiguity between two such meanings in a verb, this still concerns clearly distinct senses. The diachronic evolution of the verbs moreover shows signs of a tendency for each to develop a unique profile in the range of these meanings. In addition, the meanings appear to emerge, at least in part, along different evolutionary paths. Hence the fuzzy view of the semantics of these verbs, as it is present in at least some of the literature, is not warranted.

In addition, the special position of the subjectivity meaning offers food for thought regarding the definition of the concept of subjectification, specifically in relation to the concept of the hierarchy of qualificational categories. 


\section{References}

Aikhenvald, Alexandra Y. 2004. Evidentiality. Oxford: Oxford University Press.

Apothéloz, Denis. 2003. La rection dite 'faible'. Verbum 3. 241-262.

Bogaert, Julie Van. 2006. I guess, I suppose and I believe as pragmatic markers. BELL New Series 4. 129-149.

Bogaert, Julie Van. 2009. The grammar of complement-taking mental predicate constructions in present-day spoken British English. Doctoral dissertation, Ghent: University of Gent.

Bogaert, Julie Van. 2011. I think and other complement-taking mental predicates. Linguistics 49. 295-332. https://doi.org/10.1515/ling.2011.009

Bolinger, Dwight. 1968. Entailment and the meaning of structures. Glossa 2. 119-127.

Brinton, Laurel. 1996. Pragmatic markers in English. Berlin: de Gruyter. https://doi.org/10.1515/9783110907582

Brinton, Laurel. 2008. The comment clause in English. Cambridge: Cambridge University Press. https://doi.org/10.1017/CBO9780511551789

Byloo, Pieter \& Nuyts, Jan. 2014. Meaning change in the Dutch core modals. Acta Linguistica Hafniensia 46. 85-116. https://doi.org/10.1080/03740463.2014.955978

CD-ROM Middelnederlands. 1998. Den Haag: SDU.

Chafe, Wallace. 1986. Evidentiality in English conversation and academic writing. In Chafe, Wallace \& Nichols, Johanna (eds.), Evidentiality, 261-272. Norwood: Ablex.

Cornillie, Bert. 2007. Evidentiality and epistemic modality in Spanish. Berlin: de Gruyter. https://doi.org/10.1515/9783110204483

Croft, William. 2000. Explaining language change. Harlow: Longman.

Cuyckens, Hubert \& Shank, Christopher. 2009. A diachronic perspective on the grammaticalization of zero-complement clauses in English. In Slembrouck, Stef \& Taverniers, Miriam \& Van Herreweghe, Mieke (eds.), From 'will' to 'well', 117-134. Gent: Academia Press.

DeLancey, Scott. 1997. Mirativity. Linguistic Typology 1. 33-52. https://doi.org/10.1515/lity.1997.1.1.33

DeLancey, Scott. 2001. The mirative and evidentiality. Journal of Pragmatics 33. 369-382. https://doi.org/10.1016/S0378-2166(01)80001-1

Dendale, Patrick \& Van Bogaert, Julie. 2007. A semantic description of French lexical evidential markers and the classification of evidentials. Rivista di Linguistica 19. 65-89.

Diewald, Gabriele. 2001. Scheinen-Probleme. In Müller, Reimar \& Reis, Marga (eds.), Modalität und Modalverben im Deutschen, 87-110. Hamburg: Buske.

Givón, Talmy. 1993. English grammar. Amsterdam: Benjamins.

Grondelaers, Stefan \& Deygers, Katrien \& van Aken, Hilde \& van den Heede, Vicky \& Speelman, Dirk. 2000. Het ConDiv-corpus geschreven Nederlands. Nederlandse 


\section{Karolien Janssens - Jan Nuyts: \\ On the origins of the epistemic, evidential, and subjectivity meanings in the mental state predicates: The case of Dutch}

Taalkunde 5. 356-363.

Haan, Ferdinand de. 1999. Evidentiality in Dutch. Berkeley Linguistics Society 25. 74-85. https://doi.org/10.3765/bls.v25i1.1185

Horst, Jan van der. 2008. Geschiedenis van de Nederlandse syntaxis. Leuven: Universitaire Pers.

Ifantidou, Elly. 2001. Evidentials and relevance. Amsterdam: John Benjamins. https://doi.org/10.1075/pbns.86

Jakobson, Roman. 1957/1971. Shifters, verbal categories and Russian verb. In Jakobson, Roman (ed.), Selected Writings (Vol. II), 130-147. The Hague: Mouton.

Janssens, Karolien. 2015. The diachrony of the mental state predicates in Dutch. Unpublished doctoral dissertation. Antwerp: University of Antwerp.

Janssens, Karolien \& Nuyts, Jan. 2014. 'Nu thenke, wannan thaz geschehan si'. Nederlandse Taalkunde 19. 311-348. https://doi.org/10.5117/NEDTAA2014.3.JANS

Lyons, John. 1977. Semantics. Cambridge: Cambridge University Press. https://doi.org/10.1017/CBO9781139165693

Nuyts, Jan. 1992. Subjective vs objective modality. In Fortescue, Michael \& Harder, Peter \& Kristoffersen, Lars (eds.), Layered structure and reference in a functional perspective, 73-98. Amsterdam: Benjamins. https://doi.org/10.1075/pbns.23.06nuy

Nuyts, Jan. 2001a. Epistemic modality, language, and conceptualization. Amsterdam: Benjamins. https://doi.org/10.1075/hcp.5

Nuyts, Jan. 2001b. Subjectivity as an evidential dimension in epistemic modal expressions. Journal of Pragmatics 33. 383-400. https://doi.org/10.1016/S0378-2166(00)00009-6

Nuyts, Jan. 2005. The modal confusion. In Klinge, Alex \& Müller, Henrik Høeg (eds.), Modality, 5-38. London: Equinox.

Nuyts, Jan. 2009. The 'one-commitment-per-clause' principle. Linguistics 47. 141-171. https://doi.org/10.1515/LING.2009.005

Nuyts, Jan. 2012. Notions of (inter)subjectivity. English Text Construction 5. 53-76. https://doi.org/10.1075/etc.5.1.04nuy

Nuyts, Jan. 2014. Subjectivity in modality, and beyond. In Zuczkowski, Andrzej \& Bongelli, Ramona \& Riccioni, Ilaria \& Canestrari, Carla (eds.), Communicating certainty and uncertainty in medical, supportive and scientific contexts, 13-30. Amsterdam: Benjamins. https://doi.org/10.1075/ds.25.01nuy

Nuyts, Jan. 2015. Subjectivity. Journal of Pragmatics $86.106-110$ 10.1016/j.pragma.2015.05.015

Nuyts, Jan. 2017. Evidentiality reconsidered. In Marin-Arrese, Juana \& Haßler, Gerda \& Carretero, Marta (eds.), Evidentiality revisited, 57-83. Amsterdam: Benjamins. https://doi.org/10.1075/pbns.271.03nuy

Nuyts, Jan. 2021. Qualifying conceptualizations. In Wen, Xu \& Taylor, John R. (eds.), The Routledge handbook of cognitive linguistics, 421-432. New York: Routledge. 
https://doi.org/10.4324/9781351034708

Nuyts, Jan \& Byloo, Pieter. 2015. Competing modals. Diachronica 32. 34-68. https://doi.org/10.1075/dia.32.1.02nuy

Palander-Collin, M. 1997. A medieval case of grammaticalization, methinks. In Rissanen, Matti \& Kytö, Merja \& Heikkonen, Kirsi (eds.), Grammaticalization at work, 371-403. Berlin: de Gruyter.

Persson, Gunnar. 1993. Think in a panchronic perspective. Studia Neophilologica 65. 3-18. https://doi.org/10.1080/00393279308588103

Schneider, Stefan. 2007. Reduced parenthetical clauses as mitigators. Amsterdam: Benjamins. https://doi.org/10.1075/scl.27

Simon-Vandenbergen, Anne-Marie. 1998. I think and its Dutch equivalents in parliamentary debates. In Johansson, Stig \& Oksefjell, Signe (eds.), Corpora and crosslinguistic research, 297-317. Amsterdam: Rodopi.

Simon-Vandenbergen, Anne-Marie. 2000. The functions of $I$ think in political discourse. International Journal of Applied Linguistics 10. 41-63. 10.1111/j.14734192.2000.tb00139.x

Thompson, Sandra A. \& Mulac, Anthony. 1991. A quantitative perspective on the grammaticization of epistemic parentheticals in English. In Traugott, Elisabeth Closs \& Heine, Bernd (eds.), Approaches to grammaticalization, vol. 2, 313-329. Amsterdam: Benjamins. https://doi.org/10.1075/ts1.19.2.16 tho

Traugott, Elisabeth Closs \& Dasher, Richard B. 2002. Regularity in semantic change. Cambridge: Cambridge University Press. https://doi.org/10.1017/CBO9780511486500

Wierzbicka, Anna. 2006. English. Oxford: Oxford University Press. DOI:10.1093/acprof:oso/9780195174748.001.0001

Willett, Thomas. 1988. A cross-linguistic survey of the grammaticization of evidentiality. Studies in Language 12. 51-97. https://doi.org/10.1075/s1.12.1.04wil 


\section{Author's address:}

University of Antwerp

Prinsstraat 13, 2000 Antwerpen

E-mail: jan.nuyts@uantwerpen.be

\section{ZUM URSPRUNG VON EPISTEMISCHER MODALITÄT, EVIDENTIALITÄT UND SUBJEKTIVITÄT IN VERBEN DES DENKENS UND ERKENNENS AM BEISPIEL DES NIEDERLÄNDISCHEN}

Diese Untersuchung hat zum Ziel, einen Beitrag zur Debatte über die Art der sprecherbezogenen Bedeutungen von Verben des Denkens und Erkennens zu leisten, indem sie versucht, mithilfe einer diachronischen Korpusstudie die Entwicklung von fünf solchen Verben in der niederländischen Sprache darzustellen. Forschungsresultate zeigen, dass jedes der untersuchten Verben ein eigenes Profil im Sinne einer begrenzten Reihe von untereinander deutlich unterscheidbaren sprecherbezogenen Bedeutungen entwickelt, nämlich epistemische Modalität, Evidentialität und Subjektivität. Jede dieser Bedeutungen ist außerdem durch einen distinktiven diachronischen Entwicklungsweg gekennzeichnet. Zusätzlich veranschaulicht die Untersuchung den selbstständigen Status der Subjektivität als Bedeutungskategorie.

Schlüsselwörter: Verben des Denkens und Erkennens; sprecherbezogene Bedeutung; Diachronie; epistemische Modalität; Evidentialität; Subjektivität. 